\author{
R. Tapdigoglu ${ }^{1}$, B.T. Torebek ${ }^{2,3}$ \\ ${ }^{1}$ Université de La Rochelle, La Rochelle, France; \\ ${ }^{2}$ Institute of Mathematics and Mathematical Modeling, Almaty, Kazakhstan; \\ ${ }^{3}$ Al-Farabi Kazakh National University, Almaty, Kazakhstan \\ (E-mail: ramiz.tapdigoglu1@univ-lr.fr)
}

\title{
Inverse source problems for a wave equation with involution
}

\begin{abstract}
A class of inverse problems for a wave equation with involution is considered for cases of two different boundary conditions, namely, Dirichlet and Neumann boundary conditions. The existence and uniqueness of solutions of these problems are proved. The solutions are obtained in the form of series expansion using a set of appropriate orthogonal basises for each problem. Convergence of the obtained solutions is also justified.
\end{abstract}

Keywords: inverse problem, involution, nonlocal wave equation, Sturm-Liouville problem, existence of solution, uniqueness of solution.

\section{Introduction}

In many physical problems, determination of coefficients or right-hand side according to some available information (the source term, in case of a wave equation) in a differential equation is required; these problems are known as inverse problems. These kinds of problems are ill-posed in the sense of Hadamard.

The purpose of this paper is to study inverse problems for a nonlocal wave equation with involution of space variable $x$. We consider the nonlocal wave equation

$$
u_{t t}(x, t)-u_{x x}(x, t)+\varepsilon u_{x x}(\pi-x, t)=f(x),
$$

for $(x, t) \in \Omega=\{0<x<\pi, 0<t<T\}$, where $\varepsilon$ is a real number.

Wide opportunities for applying equations with deviating argument in mathematical models have increased the interest of the study of new problems for partial differential equations [1-3].

Among differential equations with deviating arguments, a special place is occupied by equations with a deviation of arguments of alternating character. Such deviations include the so-called deviation of involution type [4]. To describe them, let $\Gamma$ be an interval in $\mathbb{R}$ and let $X \in \Gamma$ be a real variable.

The homeomorphism

$$
\alpha^{2}(X)=\alpha(\alpha(X))=X
$$

is called a Carleman shift (deviation of involution) [5].

Equations containing Carleman shift are equations with an alternating deviation (at $X^{*}<X$ being equations with advanced, and at $X^{*}>X$ being equations with delay, where $X^{*}$ is a fixed point of the mapping $\left.\alpha(X)\right)$.

Concerning the inverse problems for partial differential equations with involutions, some recent works have been implemented in [6-11].

\section{Statement of problems}

The paper is devoted to two inverse problems concerning the wave equation with a perturbative term of involution type with respect to the space variable. We obtain existence and uniqueness results for these problems, based on the Fourier method.

Problem D. Find a couple of functions $(u(x, t), f(x))$ satisfying the equation (1), under the conditions

$$
\begin{gathered}
u(x, 0)=0, x \in[0, \pi], \\
u(x, T)=\psi(x), x \in[0, \pi], \\
u_{t}(x, 0)=0, x \in[0, \pi],
\end{gathered}
$$


and the homogeneous Dirichlet boundary conditions

$$
u(0, t)=u(\pi, t)=0, t \in[0, T],
$$

where $\psi(x)$ is a given sufficiently smooth function.

Problem $N$. Find the couple of functions $(u(x, t), f(x))$ in the domain $\Omega$ satisfying equation (1), conditions (2), (3), (4) and the homogeneous Neumann boundary conditions

$$
u_{x}(0, t)=u_{x}(\pi, t)=0, t \in[0, T] .
$$

A regular solution of the problems $\mathrm{D}$ and $\mathrm{N}$ is the pair of functions $(u(x, t), f(x))$, where $u \in C^{2}(\bar{\Omega})$ and $f \in C([0, \pi])$.

\section{Spectral properties of the perturbed Sturm-Liouville problem}

Application of the Fourier method for solving the problems D and N leads to a spectral problem defined by the equation

$$
y^{\prime \prime}(x)-\varepsilon y^{\prime \prime}(\pi-x)+\lambda y(x)=0,0<x<\pi,
$$

and one of the following boundary conditions

$$
\begin{gathered}
y(0)=y(\pi)=0 ; \\
y^{\prime}(0)=y^{\prime}(\pi)=0 .
\end{gathered}
$$

It is easy to see that the Sturm-Liouville problem for the equation (7) with one of the boundary conditions (8) and (9) is self-adjoint. It is known that the self-adjoint problem has real eigenvalues and their eigenfunctions form a complete orthonormal basis in $L^{2}(0, \pi)$ [12]. To further investigate the problems under consideration, we need to calculate the explicit form of the eigenvalues and eigenfunctions.

It is easy to show that for $|\varepsilon|<1$ the problem (7), (8) has the following eigenvalues

$$
\begin{gathered}
\lambda_{2 k}^{D}=(1+\varepsilon) 4 k^{2}, k \in \mathbb{N} ; \\
\lambda_{2 k+1}^{D}=(1-\varepsilon)(2 k+1)^{2}, k \in \mathbb{N}_{0}=\mathbb{N} \cup\{0\}
\end{gathered}
$$

and eigenfunctions

$$
\left\{\begin{array}{l}
y_{2 k}^{D}=\sqrt{\frac{2}{\pi}} \sin 2 k x, k \in \mathbb{N} \\
y_{2 k+1}^{D}=\sqrt{\frac{2}{\pi}} \sin (2 k+1) x, k \in \mathbb{N}_{0} .
\end{array}\right.
$$

Similarly, the problem (7), (9) has the eigenvalues

$$
\begin{gathered}
\lambda_{2 k+1}^{N}=(1+\varepsilon)(2 k+1)^{2}, k \in \mathbb{N}_{0} \\
\lambda_{2 k}^{N}=(1-\varepsilon) 4 k^{2}, k \in \mathbb{N}_{0},
\end{gathered}
$$

and corresponding eigenfunctions

$$
\left\{\begin{array}{l}
y_{0}^{N}=\frac{1}{\sqrt{\pi}} \\
y_{2 k+1}^{N}=\sqrt{\frac{2}{\pi}} \cos (2 k+1) x, k \in \mathbb{N}_{0} \\
y_{2 k}^{N}=\sqrt{\frac{2}{\pi}} \cos 2 k x, k \in \mathbb{N} .
\end{array}\right.
$$

The following lemma is proved in [11].

Lemma 1. The systems of functions (10) and (11) are complete and orthonormal in $L^{2}(0, \pi)$. 


\section{Main results}

For the considered problems $\mathrm{D}$ and $\mathrm{N}$, the following theorems are valid.

Theorem 1. Let $|\varepsilon|<1, \psi \in C^{4}[0, \pi]$ and $\psi^{(i)}(0)=\psi^{(i)}(\pi)=0, i=0,1,2,3$, 4. If

$$
\cos \sqrt{1-\varepsilon}(2 k+1) T<\delta_{1}<1
$$

and

$$
\cos \sqrt{1+\varepsilon} 2 k T<\delta_{2}<1,
$$

then the solution of the problem $D$ exists, is unique and it can be written in the form

$$
\begin{gathered}
u(x, t)=\sum_{k=0}^{\infty} \frac{(1-\cos \sqrt{1-\varepsilon}(2 k+1) t) \sin (2 k+1) x}{(1-\cos \sqrt{1-\varepsilon}(2 k+1) T)(2 k+1)^{4}} \psi_{2 k+1}^{4}+ \\
\quad+\sum_{k=1}^{\infty} \frac{(1-\cos \sqrt{1+\varepsilon} 2 k t) \sin 2 k x}{(1-\cos \sqrt{1+\varepsilon} 2 k T) 16 k^{4}} \psi_{2 k}^{4} ; \\
f(x)=\sum_{k=0}^{\infty} \frac{(1-\varepsilon) \psi_{2 k+1}^{4}}{(1-\cos \sqrt{1-\varepsilon}(2 k+1) T)(2 k+1)^{2}} \sin (2 k+1) x+ \\
+\sum_{k=1}^{\infty} \frac{(1+\varepsilon) \psi_{2 k}^{4}}{(1-\cos \sqrt{1+\varepsilon} 2 k T) 4 k^{2}} \sin 2 k x,
\end{gathered}
$$

where $\psi_{2 k+1}^{(4)}=\left(\psi^{(4)}(x), y_{2 k+1}^{D}\right)$ and $\psi_{2 k}^{(4)}=\left(\psi^{(4)}(x), y_{2 k}^{D}\right)$.

Theorem 2. Let $|\varepsilon|<1, \psi \in C^{4}[0, \pi]$ and $\psi^{(i)}(0)=\psi^{(i)}(\pi)=0, i=0,1,2,3,4$. If

$$
\cos \sqrt{1-\varepsilon}(2 k+1) T<\sigma_{1}<1
$$

and

$$
\cos \sqrt{1+\varepsilon} 2 k T<\sigma_{2}<1,
$$

then the solution of the problem $N$ exists, is unique and it can be written in the form

$$
\begin{aligned}
u(x, t)=\sum_{k=0}^{\infty} & \frac{(1-\cos \sqrt{1+\varepsilon}(2 k+1) t) \cos (2 k+1) x}{(1-\cos \sqrt{1+\varepsilon}(2 k+1) T)(2 k+1)^{4}} \psi_{2 k+1}^{4}+ \\
& +\sum_{k=1}^{\infty} \frac{(1-\cos \sqrt{1-\varepsilon} 2 k t) \cos 2 k x}{(1-\cos \sqrt{1-\varepsilon} 2 k T) 16 k^{4}} \psi_{2 k}^{4} \\
f(x)=\sum_{k=0}^{\infty} & \frac{(1+\varepsilon) \psi_{2 k+1}^{4}}{(1-\cos \sqrt{1+\varepsilon}(2 k+1) T)(2 k+1)^{2}} \cos (2 k+1) x+ \\
& +\sum_{k=1}^{\infty} \frac{(1-\varepsilon) \psi_{2 k}^{4}}{(1-\cos \sqrt{1-\varepsilon} 2 k T) 4 k^{2}} \cos 2 k x
\end{aligned}
$$

where $\psi_{2 k+1}^{(4)}=\left(\psi^{(4)}(x), y_{2 k+1}^{N}\right)$ and $\psi_{2 k}^{(4)}=\left(\psi^{(4)}(x), y_{2 k}^{N}\right)$.

\section{Proof of the uniqueness of the solution}

Suppose that there are two solutions $\left\{u_{1}(x, t), f_{1}(x)\right\}$ and $\left\{u_{2}(x, t), f_{2}(x)\right\}$ of the problem P. Denote

$$
u(x, t)=u_{1}(x, t)-u_{2}(x, t)
$$

and

$$
f(x)=f_{1}(x)-f_{2}(x) .
$$

Then the functions $u(x, t)$ and $f(x)$ satisfy (1) and the homogeneous conditions (2) and (5). 
Let

$$
\begin{gathered}
u_{0}(t)=\frac{1}{\sqrt{\pi}} \int_{0}^{\pi} u(x, t) d x ; \\
u_{2 k}(t)=\sqrt{\frac{2}{\pi}} \int_{0}^{\pi} u(x, t) \cos 2 k x d x, k \in \mathbb{N} ; \\
u_{2 k+1}(t)=\sqrt{\frac{2}{\pi}} \int_{0}^{\pi} u(x, t) \cos (2 k+1) x d x, k \in \mathbb{N}_{0} ; \\
f_{0}=\frac{1}{\sqrt{\pi}} \int_{0}^{\pi} f(x) d x ; \\
f_{2 k+1}=\sqrt{\frac{2}{\pi}} \int_{0}^{\pi} f(x) \cos 2 k x d x, k \in \mathbb{N} ; \\
f_{0}^{\pi} f(x) \cos (2 k+1) x d x, k \in \mathbb{N} .
\end{gathered}
$$

Applying the operator $\frac{\partial^{2}}{\partial t^{2}}$ to the equation (16) we have

$$
u_{0}^{\prime \prime}(t)=\frac{1}{\sqrt{\pi}} \int_{0}^{\pi} \mathcal{D}_{t}^{\alpha} u(x, t) d x=\frac{1}{\sqrt{\pi}} \int_{0}^{\pi}\left(u_{x x}(x, t)-\varepsilon u_{x x}(\pi-x, t)\right) d x+f_{0} .
$$

Integrating by parts and taking into account the homogeneous conditions (2) and (6), we obtain

$$
\begin{gathered}
u_{0}^{\prime \prime}(t)=f_{0}, \\
u(0)=0, u(T)=0, u^{\prime}(0)=0 .
\end{gathered}
$$

Hence it is easy to get $f_{0}=0, u_{0}(t) \equiv 0$.

In a similar way for the functions (17)-(21) it is easy to prove that

$$
f_{2 k}=0, f_{2 k+1}=0, u_{2 k}(t) \equiv 0, u_{2 k+1}(t) \equiv 0 .
$$

Further, by the completeness of the system $(10)$ in $L^{2}(0, \pi)$ we obtain

$$
f(x) \equiv 0, u(x, t) \equiv 0,0 \leq t \leq T, 0 \leq x \leq \pi .
$$

The uniqueness of the solution of the problem $\mathrm{N}$ is proved.

The uniqueness of the solution of the problem D can be proved similarly.

\section{Proof of the existence of the solution}

We give the full proof for the problem $\mathrm{D}$. The existence of the solution of the problem $\mathrm{N}$ is proved analogously.

As the eigenfunctions system (10) of the problem $\mathrm{D}$ forms an orthonormal basis in $L^{2}(0, \pi)$ (this follows from the self-adjoint problem (7), (8)), the functions $u(x, t)$ and $f(x)$ can be expanded as follows

$$
\begin{gathered}
u(x, t)=\sum_{k=0}^{\infty} u_{2 k+1}(t) \sin (2 k+1) x+\sum_{k=1}^{\infty} u_{2 k}(t) \sin 2 k x ; \\
f(x)=\sum_{k=0}^{\infty} f_{2 k+1} \sin (2 k+1) x+\sum_{k=1}^{\infty} f_{2 k} \sin 2 k x,
\end{gathered}
$$


where $f_{2 k+1}, f_{2 k}, u_{2 k+1}(t), u_{2 k}(t)$ are unknown. Substituting (22) and (23) into (1), we obtain the following equation for the functions $u_{2 k+1}(t), u_{2 k}(t)$ and the constants $f_{2 k+1}, f_{2 k}$ :

$$
\begin{gathered}
u_{2 k+1}^{\prime \prime}(t)+(1-\varepsilon)(2 k+1)^{2} u_{2 k+1}(t)=f_{2 k+1} \\
u_{2 k}^{\prime \prime}(t)+(1+\varepsilon) 4 k^{2} u_{2 k}(t)=f_{2 k} .
\end{gathered}
$$

Solving these equations [13], we obtain

$$
\begin{gathered}
u_{2 k+1}(t)=\frac{f_{2 k+1}}{(1-\varepsilon)(2 k+1)^{2}}+C_{1 k} \cos \sqrt{1-\varepsilon}(2 k+1) t+C_{2 k} \sin \sqrt{1-\varepsilon}(2 k+1) t \\
u_{2 k}(t)=\frac{f_{2 k}}{(1+\varepsilon) 4 k^{2}}+D_{1 k} \cos \sqrt{1+\varepsilon} 2 k t+D_{2 k} \sin \sqrt{1+\varepsilon} 2 k t
\end{gathered}
$$

where the constants $C_{1 k}, C_{2 k}, D_{1 k}, D_{2 k}, f_{2 k+1}, f_{2 k}$ are unknown. To find these constants, we use the conditions (2). Let $\psi_{2 k}, \psi_{2 k+1}$ be the coefficients of the expansions of $\psi(x)$

$$
\begin{gathered}
\psi_{2 k+1}=\sqrt{\frac{2}{\pi}} \int_{0}^{\pi} \psi(x) \sin (2 k+1) x d x \\
\psi_{2 k}=\sqrt{\frac{2}{\pi}} \int_{0}^{\pi} \psi(x) \sin 2 k x d x .
\end{gathered}
$$

We first find $C_{1 k}, C_{2 k}$ :

$$
\begin{gathered}
u_{2 k+1}(0)=\frac{f_{2 k+1}}{(1-\varepsilon)(2 k+1)^{2}}+C_{1 k}=0 ; \\
u_{2 k+1}^{\prime}(0)=C_{2 k}=0 ; \\
u_{2 k+1}(T)=\frac{f_{2 k+1}}{(1-\varepsilon)(2 k+1)^{2}}(1-\cos \sqrt{1-\varepsilon}(2 k+1) T)=\psi_{2 k+1} .
\end{gathered}
$$

The constant $f_{2 k+1}$ is represented as

$$
f_{2 k+1}=\frac{(1-\varepsilon)(2 k+1)^{2} \psi_{2 k+1}}{1-\cos \sqrt{1-\varepsilon}(2 k+1) T}
$$

Now we find $D_{1 k}, D_{2 k}$ :

$$
\begin{gathered}
u_{2 k}(0)=\frac{f_{2 k}}{(1+\varepsilon) 4 k^{2}}+D_{1 k}=0 ; \\
u_{2 k}^{\prime}(0)=D_{2 k}=0 \\
u_{2 k}(T)=\frac{f_{2 k}}{(1+\varepsilon) 4 k^{2}}(1-\cos \sqrt{1+\varepsilon} 2 k T)=\psi_{2 k} .
\end{gathered}
$$

For the constant $f_{2 k}$, we find:

$$
f_{2 k}=\frac{(1+\varepsilon) 4 k^{2} \psi_{2 k}}{1-\cos \sqrt{1+\varepsilon} 2 k T} .
$$

Substituting $u_{2 k}(t), u_{2 k+1}(t), f_{2 k}, f_{2 k+1}$ into (22) and (23), we find

$$
\begin{aligned}
u(x, t) & =\sum_{k=0}^{\infty} \frac{(1-\cos \sqrt{1-\varepsilon}(2 k+1) t) \sin (2 k+1) x}{(1-\cos \sqrt{1-\varepsilon}(2 k+1) T)} \psi_{2 k+1}+ \\
& +\sum_{k=1}^{\infty} \frac{(1-\cos \sqrt{1+\varepsilon} 2 k t) \sin 2 k x}{(1-\cos \sqrt{1+\varepsilon} 2 k T)} \psi_{2 k} .
\end{aligned}
$$


Suppose that

$$
\psi^{(i)}(0)=0, \psi^{(i)}(\pi)=0, i=0,1,2,3,4,
$$

then

$$
\psi_{2 k+1}=\frac{1}{(2 k+1)^{4}} \psi_{2 k+1}^{(4)}, \quad \psi_{2 k}=\frac{1}{16 k^{4}} \psi_{2 k}^{(4)}
$$

Then we have (12).

Similarly,

$$
\begin{gathered}
f(x)=\sum_{k=0}^{\infty} \frac{(1-\varepsilon) \psi_{2 k+1}^{4}}{(1-\cos \sqrt{1-\varepsilon}(2 k+1) T)(2 k+1)^{2}} \sin (2 k+1) x+ \\
+\sum_{k=1}^{\infty} \frac{(1+\varepsilon) \psi_{2 k}^{4}}{(1-\cos \sqrt{1+\varepsilon} 2 k T) 4 k^{2}} \sin 2 k x .
\end{gathered}
$$

Now for the convergence of the series, we have the following estimate

$$
\begin{aligned}
|u(x, t)| \leq & \sum_{k=0}^{\infty} \frac{(1-\cos \sqrt{1-\varepsilon}(2 k+1) t)}{(1-\cos \sqrt{1-\varepsilon}(2 k+1) T)(2 k+1)^{4}}\left|\psi_{2 k+1}^{(4)}\right|+ \\
& +\sum_{k=1}^{\infty} \frac{(1-\cos \sqrt{1+\varepsilon} 2 k t)}{(1-\cos \sqrt{1+\varepsilon} 2 k T) 16 k^{4}}\left|\psi_{2 k}^{(4)}\right| \leq \\
\leq & C \sum_{k=0}^{\infty} \frac{1}{(2 k+1)^{4}}\left|\psi_{2 k+1}^{(4)}\right|+C \sum_{k=1}^{\infty} \frac{1}{16 k^{4}}\left|\psi_{2 k}^{(4)}\right|<\infty .
\end{aligned}
$$

Similarly for $f(x)$ we obtain the estimate

$$
\begin{gathered}
|f(x)| \leq \sum_{k=0}^{\infty} \frac{(1-\varepsilon)\left|\psi_{2 k+1}^{(4)}\right|}{(1-\cos \sqrt{1-\varepsilon}(2 k+1) T)(2 k+1)^{2}}+\sum_{k=1}^{\infty} \frac{(1+\varepsilon)\left|\psi_{2 k}^{(4)}\right|}{(1-\cos \sqrt{1+\varepsilon} 2 k T) 4 k^{2}} \leq \\
\leq C \sum_{k=0}^{\infty} \frac{\left|\psi_{2 k+1}^{(4)}\right|}{(2 k+1)^{2}}+C \sum_{k=1}^{\infty} \frac{\left|\psi_{2 k}^{(4)}\right|}{4 k^{2}} .
\end{gathered}
$$

Since by hypotheses of Theorem 1 , the function $\psi^{(4)}$ is continuous on $[0, \pi]$, then by the Bessel inequality for the trigonometric series the following series converge:

$$
\begin{aligned}
& \sum_{k=1}^{\infty}\left|\psi_{2 k}^{(4)}\right|^{2} \leq C\left\|\psi^{(4)}(x)\right\|_{L_{2}(0, \pi)}^{2} \\
& \sum_{k=0}^{\infty}\left|\psi_{2 k+1}^{(4)}\right|^{2} \leq C\left\|\psi^{(4)}(x)\right\|_{L_{2}(0, \pi)}^{2}
\end{aligned}
$$

which implies the boundedness of the set

$$
\left\{\psi_{2 k}^{(4)}\right\}_{k=1}^{\infty},\left\{\psi_{2 k+1}^{(4)}\right\}_{k=0}^{\infty} .
$$

Therefore, by the Weierstrass M-test (see [14]), the series (24) and (25) converge absolutely and uniformly in the domain $\bar{\Omega}$.

Now we show the possibility of termwise differentiation of the series (24) twice in the variable $x$ and twice in the variable $t$. For this purpose, we prove that the series obtained by means of term by term differentiation converge absolutely and uniformly on $\bar{\Omega}$. Given the estimates (26) and (27) we have

$$
\left|u_{x x}(x, t)\right| \leq \sum_{k=0}^{\infty} \frac{(1-\cos \sqrt{1-\varepsilon}(2 k+1) t)}{(1-\cos \sqrt{1-\varepsilon}(2 k+1) T)(2 k+1)^{2}}\left|\psi_{2 k+1}^{(4)}\right|+
$$




$$
\begin{gathered}
+\sum_{k=1}^{\infty} \frac{(1-\cos \sqrt{1+\varepsilon} 2 k t)}{(1-\cos \sqrt{1+\varepsilon} 2 k T) 4 k^{2}}\left|\psi_{2 k}^{(4)}\right| \leq \\
\leq C \sum_{k=0}^{\infty} \frac{1}{(2 k+1)^{2}}\left|\psi_{2 k+1}^{(4)}\right|+C \sum_{k=1}^{\infty} \frac{1}{4 k^{2}}\left|\psi_{2 k}^{(4)}\right|<\infty \\
\left|u_{t t}(x, t)\right| \leq \sqrt{1-\varepsilon} \sum_{k=0}^{\infty} \frac{(|\sin \sqrt{1-\varepsilon}(2 k+1) t|)}{(1-\cos \sqrt{1-\varepsilon}(2 k+1) T)(2 k+1)^{2}}\left|\psi_{2 k+1}^{(4)}\right|+ \\
+\sqrt{1+\varepsilon} \sum_{k=1}^{\infty} \frac{|\sin \sqrt{1+\varepsilon} 2 k t|}{(1-\cos \sqrt{1+\varepsilon} 2 k T) 4 k^{2}}\left|\psi_{2 k}^{(4)}\right| \leq \\
\leq C \sum_{k=0}^{\infty} \frac{1}{(2 k+1)^{2}}\left|\psi_{2 k+1}^{(4)}\right|+C \sum_{k=1}^{\infty} \frac{1}{4 k^{2}}\left|\psi_{2 k}^{(4)}\right|<\infty . \\
\text { Acknowledgements }
\end{gathered}
$$

The second named author is financially supported by a grant from the Ministry of Science and Education of the Republic of Kazakhstan (Grant No. AP05131756).

References

1 Bzheumikhova, O.I. (2013). International Journal of Differential Equations and Applications, 12, 2, $103-120$.

2 Hernandez, E. (2006). Nonlinear Analysis, R.W.A., 4, 510-519.

3 Rezounenko, A.V. (2008). Electronic Journal of Qualitative Theory of Differential Equations, 17, 1-7.

4 Cabada, A., \& Tojo, F.A.F. (2015). Differential Equations with Involutions, Atlantis Press.

5 Carleman, T. (1932). Verhandl. des internat. Mathem. Kongr., Zurich, I, 138-151.

6 Ahmad, B., Alsaedi, A., Kirane, M., \& Tapdigoglu, R. (2017). Quaestiones Mathematicae, 40, 2, 151-160.

7 Al-Salti, N., Kirane, M., \& Torebek, B.T. (2017). Hacettepe Journal of Mathematics and Statistics. Doi: 10.15672/HJMS.2017.538.

8 Kirane, M., \& Al-Salti, N. (2016). J. Nonlinear Sci. Appl., 9, 1243-1251.

9 Kirane, M., Samet, B., \& Torebek, B.T. (2017). Electronic Journal of Differential Equations, 257, 1-13.

10 Sadybekov, M.A., Dildabek, G., \& Ivanova, M.B. (2018). Advances in Mathematical Physics, Article ID 8301656, Doi: $10.1155 / 2018 / 8301656$.

11 Torebek, B.T., \& Tapdigoglu, R. (2017). Mathematical Methods in the Applied Sciences, 40, 18, 6468-6479.

12 Naimark, M.A. (1968). Linear Differential Operators Part II, Ungar, New York.

13 Kilbas, A.A., Srivastava, H.M., \& Trujillo, J.J. (2006). Theory and Applications of Fractional Differential Equations, Elsevier, North-Holland, Mathematics studies.

14 Knopp, K. (1996). Theory of Functions Parts I and II, Two Volumes Bound as One, Part I. New York: Dover.

\section{Р. Тапдигоглу, Б.Т. Төребек}

\section{Инволюциялы толқын теңдеуі үшін дереккөзді кері есептер}

Мақалада екі түрлі шекаралық шартпен, атап айтқанда, Дирихле және Нейман шекаралық шарттарымен берілген инволюциясы толқын теңдеуі үшін кері есептер класы қарастырылды. Осы есептердің шешімінің бар болуы мен жалғыздығы дәлелденді. Шешім әрбір есептің сәйкес ортогоналды базистері арқылы жіктелген қатар арқылы алынды. Ол шешімдердің жинақтылығы дәлелденді.

Kiлm сөздер: кері есеп, инволюция, бейлокал толқын теңдеуі, Штурм-Лиувилл есебі, шешімнің бар болуы, шешімнің жалғыздығы. 
Р. Тапдигоглу, Б.Т. Торебек

\section{Обратные задачи источника для волнового уравнения с инволюцией}

В статье рассмотрен класс обратных задач для волнового уравнения с инволюцией для случаев двух разных граничных условий, а именно граничных условий Дирихле и Неймана. Доказаны существование и единственность решений этих задач. Решения получены в виде разложения рядов с использованием набора подходящих ортогональных базисов для каждой задачи. Также доказана сходимость полученных решений.

Ключевые слова: обратная задача, инволюция, нелокальное волновое уравнение, задача ШтурмаЛиувилля, существование решения, единственность решения. 